\title{
最近の歯学
}

\section{3. 小监菌科}

永久歯と乳歯の象牙質有機基質の組成の違い

東京医科秚科大学菌学部小児歯科学教室 長 井 博 昭

小児歯科臨床においては, 嚙蝕に対する感受性や根尖 病巣による歯質の吸収の程度などが, 永久歯と乳歯とで は異なるような所見がしばしば観察される。これまでこ のような永久歯と乳歯の反応性の違いを説明するため に, 両者の物理化学的性状の違いに関して調べられてき た。そこでこれまで, 象牙質の無機成分の組成や硬度や 比重なとについては永久歯と乳歯との間に差がないが, 結晶粒子の大きさは永久歯のほ 5 が乳歯より大きいこ と1などが報告された。また，酸やEDTAを用いて歯質 を脱灰して双ると, 永久柬の注らが乳歯より脱灰されに くいが,エチレンジアミンを用いて脱有機化した後に脱 灰すると, 永久歯のほらが乳歯よりも脱灰されやすくな ることが報告された2)。このことは，雨質の有機基質成 分が歯質の反応性に関与している可能性があることを示 㖫している。

ところで最近, ウシ永久歯の象牙質の有機基質組成が 歯冠部と崠根部とで異なっていることが報告されだ)。 そこで， ウシ切歯を用いて，永久歯と乳歯の有機基質の 組成を歯冠部と歯根部に分けて比較した。塩酸グアニジ ンおよび EDTA を用いて, 分子量 1,000 以上の非ュラー ゲン性タンパク質を G-extract および E-extract の二 段階に分けてほぼすべて抽出した。両 extractを SDS 電気泳動によってそれぞれ組成を比較したところ，永久 雨と乳雪あるい、米冠部と歯根部との間で組成が異な っていることがわかった。さらに，その差の㩆著な $\mathrm{E}-$ extractについて, DEAE セルロースイオン交換クロマ トグラフィーによって七つの画分に分画した後に, 同様 に電気泳動で組成をそれぞれ比較したところ，画分 7 に は永久歯の歯根部にのみ明確に認められるタンパク質が みつかった（図 1)。このタンパク質は分子量が30, 300 で，各種クロマトグラフィーを用いて分離精製した後に アミノ酸組成を調べたところグリシン，ロイシン，グル タミン酸が多いことがわかった。

これまで，永久歯と乳歯の象牙質の有機基質成分の違 いについては具体的に明らかにされてはいない。しか
し，以上のように両者を詳細に比較して及ると，永久米 と乳歯とでは象牙質の有機基質の組成が異なっており, しか子永久歯の歯根部にの又認められるタンパ質が存 在することが明らかになった。

\section{文献}

1）高橋守夫：歯質の理化学的研究 (特に乳歯, 永 久歯の差異に関寸る結晶学的考察). 日保歯誌 4 : 56-73, 1961.

2）神山紀久男: 乳歯歯質に関寸る生化学的研究. 口病誌 $32: 74-81,1965$.

3) Takagi, Y., Nagai, H. and Sasaki, S. : Difference in noncollagenous matrix composition between crown and root dentin of bovine incisor. Calcif. Tissue Int. 42: 97-103, 1988.

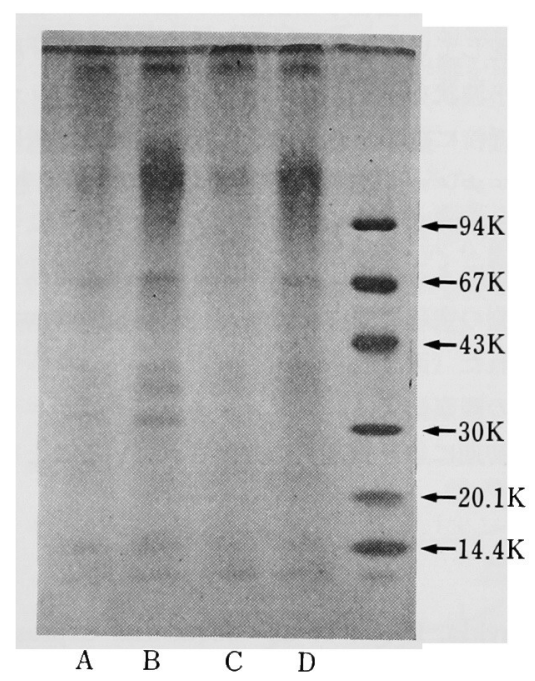

図 1 E-extract の DEAEセルロース イオン交換クロマトグラフィー 画分 7 の SDS 電気泳動像

$\mathrm{A}$ は永久歯歯冠部, $\mathrm{B}$ は永久歯歯根 部, C は乳歯歯冠部, D任歯歯根部 の E-extract の DEAE 画分 7 を示す 